\title{
Pengaruh Model Project Based Learning Berbantuan Media Virtual Terhadap Penguasaan Konsep Peserta didik pada Materi Alat-alat Optik
}

\author{
Ni Made Yeni Suranti' ${ }^{1}$, Gunawan ${ }^{2}$, Hairunnisyah Sahidu ${ }^{3}$ \\ Program Studi Pendidikan Fisika \\ FKIP Universitas Mataram \\ Mataram, Indonesia \\ Email: surantiyeni@gmail.com
}

\begin{abstract}
Learning physics should be able to provide an understanding physics of abstract concepts. One of the efforts being made to improve the learning of Physics is to use appropriate learning model. This study aims to improve the student's conceptual understanding by using project based learning model with virtual media for X Grade student at SMAN 2 Mataram Years 2015/2016. This study was conducted using a type of quasi-experimental research, untreated control group design with pretest and posttest on Optic. Hypothesis test results that the model used to give effect to the student's conceptual understanding, was shown to increase student conceptual understanding was higher in the experimental class compared with the control class. $N$-gain test results stating that the conceptual understanding has increased in each sub material. The results of the analysis conceptual understanding score on every aspect of cognitive increased.
\end{abstract}

Keywords: project base learning, virtual media, conceptual understanding.

\section{Pendahuluan}

Proses pembelajaran sebagai salah satu komponen pendidikan hendaknya menyenangkan dan dapat memotivasi peserta didik untuk berpartisipasi aktif, serta memberi ruang untuk berkreasi. Guru sebagai salah satu komponen dalam proses pembelajaran harus terampil dalam menggunakan model dan media pembelajaran yang tepat. Tanpa penggunaan model dan media yang jelas, proses pembelajaran menjadi tidak terarah dan tidak menghasilkan hasil yang optimal. Model dan media pembelajaran yang digunakan guru diharapkan mampu mempermudah guru dalam menyampaikan materi sehingga peserta didik dapat menguasai konsep dengan baik.

Fisika sebagai salah satu bagian IPA berperan penting dalam membentuk peserta didik yang berkualitas. Fisika merupakan pengetahuan, gagasan dan konsep tentang alam sekitar yang diperoleh dari pengalaman melalui pengamatan dan diaplikasikan dalam dunia nyata [1]. Fisika memiliki konsep, prinsip dan hukum. Gunawan [2] menyatakan bahwa "beberapa konsep fisika termasuk konsep yang abstrak". Konsep fisika yang abstrak sering kali menjadi kendala bagi guru dalam menyampaikan materi kepada peserta didik, sehingga peserta didik belum optimal dalam memahami konsep yang dijelaskan guru. Hal ini tentunya berdampak pada minat belajar peserta didik dalam menerima pelajaran fisika yang menyebabkan rendahnya penguasaan konsep peserta didik untuk menyelesaikan suatu persoalan.

Permasalahan yang sering terjadi dalam proses pembelajaran fisika adalah penggunaan model pembelajaran yang belum optimal. Penggunaan model pembelajaran yang kurang sesuai dengan kemampuan peserta didik membuat suasana belajar yang monoton bahkan kadang membosankan. Hal ini membatasi kemampuan peserta didik dalam menemukan dan mencoba hal-hal baru. Anggapan bahwa fisika rumit menyebabkan antusias peserta didik dalam mengajukan pertanyaan dan berdiskusi dengan guru masih belum optimal. Kurangnya minat belajar peserta didik menyebabkan penguasaan konsep masih rendah. Menyikapi permasalahan tersebut ditawarkan model project based learning yang dapat meningkatkan penguasaan konsep peserta didik.

Project based learning merupakan pembelajaran inovatif yang berpusat pada peserta didik (student centered) dan menempatkan guru sebagai motivator dan fasilitator, di mana peserta didik diberi peluang bekerja secara otonom mengkonstruksi belajarnya [3]. Model project based learning mengarahkan peserta didik pada permasalahan secara langsung kemudian penyelesaiannya melibatkan kerja proyek yang secara tidak langsung aktif dan dilatih untuk bertindak maupun berpikir kreatif. Dalam penelitian Yance [4] menyimpulkan bahwa model project based leraning dapat meningkatkan hasil belajar fisika pada ranah afektif, kognitif dan psikomotorik. Sebanding dengan penelitian Condliffe [5] yang menyimpulkan bahwa model project based learning mampu memberikan pengaruh yang positif terhadap kemampuan kognitif.

Pembelajaran project based learning di dalam kelas dapat dioptimalkan dengan menggunakan bantuan media pembelajaran. Media pembelajaran dapat membangkitkan motivasi peserta didik untuk belajar dan sangat membantu keefektifan proses pembelajaran. Media pembelajaran yang digunakan peneliti berupa media virtual. Media virtual merupakan media yang berbasis komputer. Gunawan [6] menyatakan bahwa pembelajaran berbasis komputer dapat meningkatkan motivasi belajar 
peserta didik, peserta didik dapat belajar lebih mandiri dan berkreasi.

Berdasarkan uraian di atas, permasalahannya yaitu menguji pengaruh model project based learning berbantuan media virtual terhadap penguasaan konsep fisika peserta didik.

\section{TINJAUAN PUSTAKA}

\section{A. Project Based Learning}

Project based learning adalah pembelajaran inovatif yang mendorong peserta didik untuk melakukan penyelidikan bekerja secara kolaboratif dalam meneliti dan membuat proyek yang menerapkan pengetahuan mereka dari menemukan hal-hal baru, mahir dalam penggunaan teknologi dan mampu menyelesaikan permasalahan [7]. Proyek hendaknya menantang para peserta didik untuk melakukan dan menyelesaikannya. Dalam pelaksaan project based learning, lingkungan belajar harus didesain sedemikian rupa sehingga peserta didik dapat melakukan penyelidikan terhadap masalah-masalah nyata termasuk pendalaman suatu materi dari suatu topik mata pelajaran dan melaksanakan tugas bermakna lainnya [3]. Project based learning merupakan metode yang efektif untuk mengajarkan peserta didik proses yang kompleks dan prosedur seperti perencanaan, komunikasi, pemecahan masalah, dan pengambilan keputusan [8]. Keefektifan project based learning juga diungkapkan oleh Asan [9] bahwa model tersebut menawarkan kesempatan untuk menerapkan pengetahuan teoritis dan praktis, dan untuk mengembangkan kerja kelompok peserta didik, dan keterampilan kolaborasi.

Adapun langkah-langkah pembelajaran dalam project based learning yang dikembangkan oleh The George Lucas Educational Foundation (George Lucas, 2005) [3] terdiri dari : (1) Dimulai dengan pertanyaan yang esensial. Topik yang diambil sesuai dengan realitas dunia nyata dan dimulai dengan suatu investigasi mendalam. Pertanyaan esensial diajukan untuk memancing pengetahuan, tanggapan, kritik dan ide peserta didik mengenai tema proyek yang akan diangkat; (2) Perencanaan aturan pengerjaan proyek. Perencanaan berisi tentang aturan main, pemilihan aktivitas yang mendukung dalam menjawab pertanyaan esensial, dengan cara mengintegrasikan berbagai subjek yang mungkin, serta mengetahui alat dan bahan yang dapat diakses untuk membantu penyelesaian proyek; (3) Membuat jadwal aktivitas. Guru dan peserta didik secara kolaboratif menyusun jadwal dalam menyelesaikan proyek. Jadwal ini disusun untuk mengetahui berapa lama waktu yang dibutuhkan dalam pengerjaan proyek; (4) Memonitor perkembangan proyek peserta didik. Guru bertanggung jawab untuk melakukan monitor terhadap aktivitas peserta didik selama menyelesaikan proyek. Kegiatan ini dilakukan dengan cara menfasilitasi peserta didik pada setiap proses; (5)
Penilaian hasil kerja peserta didik. Penilaian dilakukan untuk membantu guru dalam mengukur ketercapaian standar, berperan dalam mengevaluasi kemajuan masing-masing peserta didik, memberi umpan balik tentang tingkat pemahaman yang sudah dicapai peserta didik, membantu guru dalam menyusun strategi pembelajaran berikutnya; (6) Evaluasi pengalaman belajar peserta didik. Pada akhir proses pembelajaran, guru dan peserta didik melakukan refleksi terhadap aktivitas dan hasil proyek yang sudah dijalankan. Proses refleksi dilakukan baik secara individu maupun kelompok. Pada tahap ini peserta didik diminta untuk mengungkapkan perasaan dan pengalamannya selama menyelesaikan proyek.

\section{B. Media Virtual}

Media virtual merupakan media sistem digital dalam teknologi komputer yang digunakan untuk menyampaikan pembelajaran berupa metode eksperimen. Media virtual atau laboratorium virtual memiliki peralatan dan bahan seperti yang digunakan dalam eksperimen nyata. Laboratorium virtual didefinisikan sebagai suatu bentuk objek multimedia interaktif yang terdiri dari berbagai format heterogen seperti teks, hiperteks, suara, gambar, animasi video, dan grafik [6].

Pembelajaran dengan virtual laboratory menyebabkan keterampilan generik sains, kemampuan infersi logika dan kemampuan membangun konsep lebih baik [2]. Aldrich [10] mengungkapkan bahwa, peserta didik yang belajar melalui model simulasi virtual memiliki kemampuan yang lebih tinggi untuk menjelaskan dan memahami materi yang telah dipelajari.

Laboratorium virtual juga dimaksudkan untuk memberikan pengalaman untuk memecahkan masalah pada situasi yang ada. Laboratorium virtual sangat membantu untuk meningkatkan minat dan motivasi keterampilan dengan memberikan keamanan sepenuhnya untuk segi waktu [11]. Sedangkan menurut Oidov [12] mengungkapkan bahwa laboratorium virtual bermanfaat dalam memberikan kesempatan peserta didik untuk belajar dengan melakukan, mengembangkan kemampuan berpikir dan keterampilan dalam pemecahan masalah.

Gunawan [6] mengungkapkan bahwa pembelajaran dengan laboratorium virtual di kelas, dapat dibagi menjadi 4 tahapan sesuai dengan alokasi waktu yang disiapkan, yaitu: Introduction. Pada tahap ini setiap peserta didik diberikan panduan dan dijelaskan setiap fungsi dari desain dan uji yang akan dilaksanakan. Periode ini sebaiknya dibuat efisien, singkat dan jelas. Brainstrorming. Setiap peserta didik mengidentifikasi keriteria desain dan kendala, menulis rencana desain, termasuk pada identifikasi data apa saja yang perlu dibandingkan. Brainstrorming adalah teknik kreativitas individu atau kelompok dimana diusahakan untuk menemukan kesimpulan dari suatu 
masalah tertentu dengan mengumpulkan daftar ide spontan yang disumbangkan oleh setiap anggotanya. Design. Pada tahap ini peserta didik mendesain dan menguji desain yang dikembangkan. Pada tahap ini penting setiap kata direkam dan disimpan oleh peserta didik. Share. Pada tahap ini peserta didik berbagi hasil dan berpasrtisipasi secara aktif dalam diskusi kelas.

\section{Project Based Learning berbantuan Media Virtual}

Model project based learning ini adalah model pembelajaran yang menghadapkan peserta didik kepada proyek diawali dengan pertanyaan yang esensial dengan mengambil masalah sesuai dengan dunia nyata. Kemudian media virtual diperkenalkan peserta didik dalam perencanaan pengerjaan proyek. Selanjutnya guru bersama peserta didik membuat jadwal aktivitas dalam pengerjaan proyek. Dimana proyek yang dimaksud adalah berupa lembar kerja yang harus diselesaikan peserta didik dengan menggunakan media virtual. Kegiatan tersebut harus di-monitoring oleh guru untuk mengecek perkembangan proyek yang dikerjakan peserta didik. Selanjutnya guru melakukan penilaian terhadap hasil kerja peserta didik berupa lembar kerja pada setiap pertemuan. Pada akhir pembelajaran guru juga akan memberikan penilaian terhadap kumpulan lembar kerja/proyek dalam bentuk produk yang dihasilkan. Pada tahap evaluasi guru akan melakukan refleksi terhadap proyek yang sudah dikerjakan.

\section{Penguasaan Konsep}

Konsep merupakan dasar bagi proses mental yang lebih tinggi untuk merumuskan prinsip dan generalisasi [13]. Ia mengungkapkan belajar konsep adalah hasil utama pendidikan. Senada dengan hal tersebut Anderson [14] mengungkapkan tentang pengetahuan konseptual mencakup pengetahuan tentang kategori, klasifikasi, dan hubungan antara dua atau lebih kategori atau klasifikasi pengetahuan yang lebih kompleks. Secara garis besar konsep menjelaskan gambaran suatu peristiwa. Pentingnya seseorang menguasai suatu konsep adalah agar ia mampu berkomunikasi, mengklasifikasikan ide, gagasan atau peristiwa yang dialaminya dalam kehidupan sehari-hari.

Pencapaian peserta didik dalam memahami suatu konsep menjadi salah satu indikator keberhasilan dalam proses pembelajaran. Menurut Winkel dalam Silaban [15], penguasaan konsep sebagai suatu pemahaman dengan menggunakan konsep, kaidah dan prinsip. Penguasaan konsep menjadi salah satu aspek dalam mengukur hasil suatu pembelajaran. Dalam penelitian ini penguasaan konsep yang dimaksud adalah kemampuan kognitif. Kategorikategori dalam dimensi penguasaan konsep tersebut meliputi, C1 (mengingat), C2 (memahami), C3 (mengaplikasi), $\quad \mathrm{C} 4 \quad$ (menganalisis), (mengevaluasi), dan C6 (mencipta). Penguasaan konsep fisika peserta didik yang telah diperoleh tersebut dapat menumbuhkan kreativitas peserta didik dalam memecahkan suatu persoalan. Berdasarkan uraian di atas peneliti mendefinisikan penguasaan konsep adalah suatu kemampuan kognitif peserta didik pada materi alat-alat optik yang dapat diukur melalui kategori C1 sampai C6 (mengetahui sampai mencipta).

\section{METODE PENELITIAN}

Jenis penelitian ini adalah penelitian kuasi eksperimen dengan desain penelitiannya untreated control group design with pretest and posttest. Penelitian terlaksana selama 10 bulan mulai dari September 2015 sampai bulan Juni 2016. Penelitian ini dilakukan pada peserta didik SMAN 2 Mataram kelas X dengan teknik pemilihan sampel yaitu purposive sampling yang berjumlah 67 orang, 33 orang berfungsi sebagai kelas kontrol dan 34 orang berfungsi sebagai kelas eksperimen.

Penelitian ini melibatkan beberapa variabel yang dikelompokan sebagai berikut: (1) variabel bebas pada penelitian ini yaitu model pembelajaran. Kelas eksperimen diberikan perlakuan berupa model project based learning berbantuan media virtual, sedangkan kelas kontrol diberikan perlakuan berupa pembelajaran konvensional; (2) variabel terikat dalam penelitian ini adalah penguasaan konsep peserta didik; (3) variabel kontrol dalam penelitian ini adalah guru, materi,tujuan pembelajaran, instrumen, alokasi waktu pembelajaran dan cara penilaian dikondisikan sama.

Teknik pengumpulan data dengan menggunakan tes berbentuk pilihan ganda (multiple choice) sebanyak 25 item dalam komponen kognitif dari $\mathrm{C} 1$ sampai C6 dengan lima pilihan jawaban untuk memperoleh gambaran penguasaan konsep. Tes penguasaan konsep dilakukan berbagai macam pengujian yang meliputi uji validitas, uji reliabilitas, uji tingkat kesukaran dan uji daya beda. Uji prasayarat analisis data menggunakan uji homogenitas dan uji normalitas data. Uji analisis data dilakukan dengan uji t polled varian. Data hasil penguasaan konsep yang diperoleh dianalisis dengan uji $\mathrm{N}$-gain untuk mengetahui tingkat keberhasilan penggunaan model project based learning berbantuan media virtual pada setiap sub materi alat optik. Uji ini dilakukan untuk menghindari hasil kesimpulan bias pada penelitian.

\section{HASIL DAN PEMBAHASAN}

Hasil penelitian ini diperoleh dengan pemberian tes awal dan tes akhir yang berbentuk soal pilihan ganda sebanyak 25 soal untuk mengukur penguasaan konsep.

Penelitian ini bertujuan untuk menganalisis penguasaan konsep peserta didik dengan menerapkan model project based learning yang dibantu dengan 
media virtual yang melibatkan kelas eksperimen dan kelas kontrol. Hasil penelitian ini diperoleh dari pemberian tes awal dan tes akhir yang berbentuk pilihan ganda sebanyak 25 soal. Soal yang digunakan digunakan telah divalidasi dengan mengujicobakan soal tersebut pada sekelompok peserta didik yang telah mempelajari materi alat-alat optik. Berdasarkan pemberian tes awal dan tes akhir pada kedua kelas terlihat bahwa adanya peningkatan penguasaan konsep kedua kelas yang terlihat pada Tabel 1 .

Tabel 1. Perolehan Skor Rata-rata Kedua Kelas

Kelas Kemampuan Rata-Rata Persentase
(\%)

\begin{tabular}{llll}
\hline \multirow{3}{*}{ Eksperimen } & Awal & 26 & 46 \\
& Akhir & 72 & \\
Kontrol & Awal & 25.45 & 40.97 \\
\hline
\end{tabular}

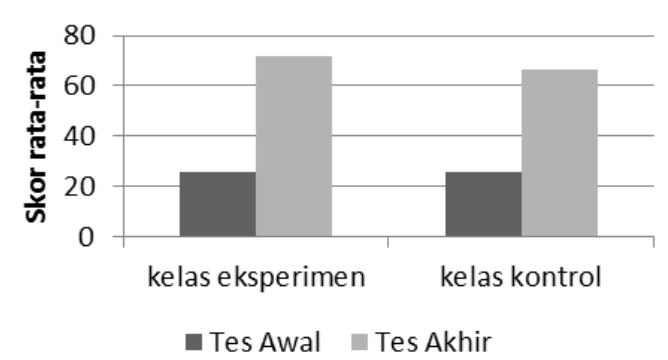

Gambar 1. Perbandingan Skor Rata-rata Kedua Kelas

Kelas eksperimen yang diberikan perlakuan memperoleh skor rata-rata yang lebih tinggi dibanding kelas kontrol yang tidak diberi perlakuan. Pada grafik, rentang peningkatan skor tes awal dengan tes akhir pada kelas eksperimen lebih tinggi dibandingkan kelas kontrol. Kelas eksperimen mengalami peningkatan skor sebesar $46 \%$ dan kelas kontrol hanya mengalami peningkatan sebesar $40.97 \%$. Pengujian data diawali dari pengujian homogenitas data dan normalitas data tes awal dan tes akhir untuk menentukan jenis uji-t yang digunakan. Berdasarkan data yang diperoleh menunjukan bahwa data tes awal dan tes akhir baik itu kelas eksperimen maupun kelas kontrol bersifat homogen dan normal.

Berdasarkan tabel terlihat bahwa pada tes awal $\mathrm{F}_{\text {hitung }}<\mathrm{F}_{\text {tabel }}$ yaitu $1.125<1.76$, maka kedua sampel dikatakan homogen. Pada tes akhir juga terlihat bahwa Fhitung < Ftabel yaitu $1.37<1.74$, sehingga kedua sampel dikatakan homogen. Hasil uji normalitas data juga menunjukan bahwa data terdistribusi normal dimana untuk kelas eksperimen dan kontrol nilai $\chi^{2}$ Hitung sebesar 9.45 dan 5.09 sedangkan nilai $\chi^{2}$ tabel sebesar 11.07. hasil tersebut menunjukan bahwa nilai $\chi^{2}{ }_{\text {hitung }}<\chi_{\text {tabel }}^{2}$ yang berarti data terdistribusi normal. Kedua kelas selanjutnya diberikan perlakuan dengan model yang berbeda, yaitu model project based learning pada kelas eksperimen dan model konvensional untuk kelas kontrol. Kedua kelas memiliki jumlah peserta didik yang berbeda yaitu 33 peserta didik kelas kontrol dan
34 peserta didik kelas eksperimen. Setelah pembelajaran, kedua kelas diberikan tes akhir. Berdasarkan tes akhir dapat diketahui, adanya peningkatan pada kedua kelas. Peningkatan penguasaan konsep kedua kelas tersebut berbeda secara signifikan. Selanjutnya dilakukan uji hipotesis (uji-t). Uji-t yang digunakan adalah uji-t polled varian. Hasil uji statistik (uji-t) menunjukkan nilai $t_{\text {hitung }}=2.25$. Harga ini lebih besar dari harga $t_{\text {tabel }}=$ 2.00 pada taraf signifikansi 5\%. Hal ini menunjukkan bahwa penguasaan konsep peserta didik yang diberikan perlakuan model project based learning berbantuan media virtual lebih baik dari pada peserta didik yang belajar dengan menggunakan model konvensional. Dengan kata lain, penggunaan model project based learning berbantuan media virtual berpengaruh terhadap penguasaan konsep fisika peserta didik. Hasil dari penelitian ini juga diperkuat oleh penelitian sebelumnya yaitu oleh Bell [7] yang menyatakan bahwa model project based learning dapat membantu peserta didik dalam memahami halhal baru dan memecahkan suatu masalah. Tentunya hal ini akan mendukung pemahaman peserta didik mengenai konsep-konsep yang diajarkan. Penelitian Zacharia [16], menyimpulkan bahwa laboratorium virtual efektif dalam meningkatkan kemampuan dalam memahami suatu konsep. Berbeda dengan penelitian Herga [17] membuktikan bahwa dengan laboratorium virtual dapat menimbulkan pemahaman peserta didik yang lebih baik pada mata pelajaran kimia. Hasil-hasil penelitian tersebut memperkuat penemuan peneliti bahwa dengan menggunakan model project based learning berbantuan media virtual juga dapat meningkatkan penguasaan konsep fisika peserta didik.

Perolehan skor penguasaan konsep juga dianalisis peningkatannya pada setiap aspek kognitif. Hasil analisis peningkatan penguasaan konsep fisika peserta didik yang dilihat dari aspek kognitif C1 hingga C6 juga mengalami peningkatan yang cukup signifikan

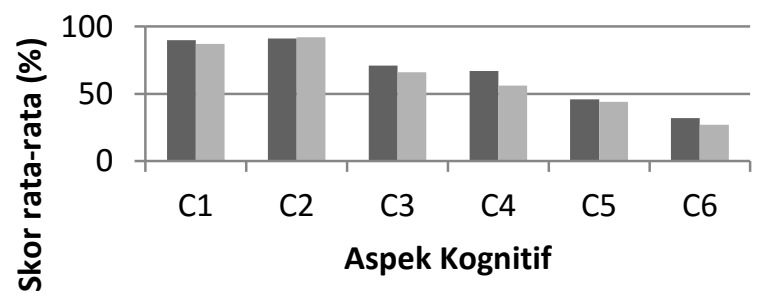

Kelas Eksperimen Kelas Kontrol

pada kedua kelas. Gambar 2. Perbandingan Perolehan Skor Tes Akhir
untuk Setiap Aspek Kognitif

Terdapat perbedaan peningkatan penguasaan konsep pada kelas eksperimen dan pada kelas kontrol. Perbandingan hasil tes akhir penguasaan konsep yang dikaji dari aspek kognitif menunjukkan bahwa secara 
keseluruhan penguasaan konsep kelas eksperimen lebih tinggi dibandingkan kelas kontrol, kecuali pada aspek kognitif C2 (memahami). Pada aspek C2 kelas kontrol lebih tinggi $1 \%$ dibandingkan kelas eksperimen. Hal ini terjadi diantaranya karena kemampuan kelas eksperimen dan kelas kontrol setelah pembelajaran memang cukup baik. Selain itu juga dipengaruhi bahwa kelas kontrol yang menerima pembelajaran konvensional sering dilatih untuk mengerjakan soal-soal latihan. Berbeda dengan penelitian Rais [18] yang menyatakan bahwa penerapan project based learning lebih unggul untuk mengajarkan materi dalam ranah kognitif yang lebih tinggi seperti penerapan, analisis, sintesis dan evaluasi. Sebaliknya materi yang berada dalam ranah kognitif lebih rendah kurang cocok diajarkan dengan project based learning. Hasil temuan peneliti yang berbeda tersebut disebabkan karena instrumen penilaian untuk aspek kognitif rendah tergolong dalam kategori soal mudah dan sedang, sehingga peserta didik dapat menjawab dengan baik. Selain itu juga dengan melibatkan media virtual dapat membantu peserta didik memperoleh konsep yang dipelajarinya. Temuan dalam penelitian ini mampu menunjukkan bahwa model dan media yang diterapkan pada kelas eksperimen mampu meningkatkan penguasaan konsep yang lebih tinggi di setiap aspek kognitif dibandingkan dengan kelas kontrol yang menerima pembelajaran konvensional.

Penguasaan konsep yang lebih tinggi terlihat pada peningkatan penguasaan konsep peserta didik yang ditinjau berdasarkan nilai $\mathrm{N}$-gain antara kelas eksperimen dan kelas kontrol yang dianalisis pada setiap sub materi alat-alat optik yang ditunjukan pada Tabel 2 berikut.

Tabel 2. Perolehan Skor N-Gain Kedua Kelas

\begin{tabular}{lll}
\hline & Kelas Eksperimen & Kelas Kontrol \\
\cline { 2 - 3 } Sub Materi & N-gain (\%) & N-gain (\%) \\
\hline Mata & 70 & 71 \\
Lup & 57 & 46 \\
Kamera & 40 & 39 \\
Mikroskop & 61 & 51 \\
Teropong & 58 & 46 \\
\hline
\end{tabular}

Persentase pencapaian skor rata-rata tes awal, tes akhir dan $\mathrm{N}$-gain penguasaan konsep antara kelas eksperimen dan kelas kontrol ditampilkan pada Gambar 3. Dari rata-rata N-gain dapat diketahui bahwa peningkatan penguasaan konsep peserta didik kelas eksperimen lebih tinggi dibandingkan kelas kontrol.

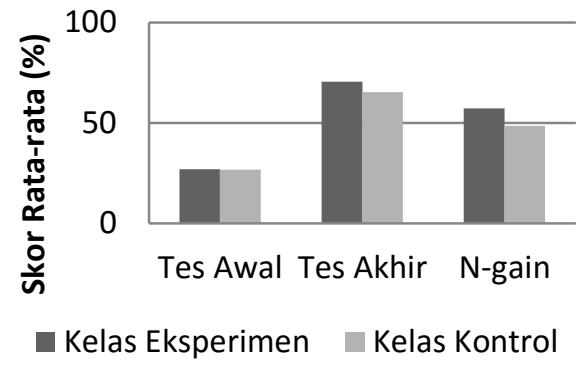

Gambar 3.Perbandingan Skor Rata-rata Penguasaan Konsep

Perbandingan peningkatan hasil belajar peserta didik per sub materi alat-alat optik tersaji dalam Gambar 4.

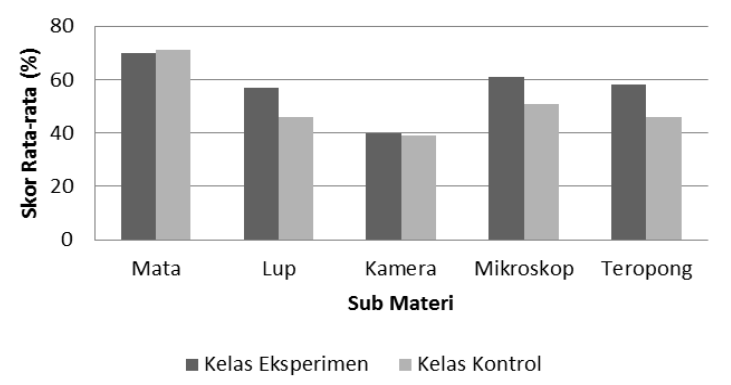

Gambar 4.Perbandingan Skor N-gain pada Sub Materi

Perbandingan hasil uji $\mathrm{N}$-gain sub materi mata pada kelas eksperimen dan kelas kontrol menunjukkan bahwa kelas kontrol lebih tinggi 1\% dibandingkan kelas eksperimen. Hal ini menunjukkan bahwa kelas eksperimen dan kelas kontrol memiliki kemampuan yang cenderung sama. Sub materi mata sebelumnya sudah pernah dipelajari peserta didik di jenjang sekolah menengah pertama sehingga lebih memudahkan peserta didik dalam belajar untuk menguasai konsep. Selain itu kelas kontrol dengan pembelajaran konvensional sering diberikan soal latihan, sehingga peserta didik sudah terbiasa menjawab soal-soal latihan tentang sub materi mata. Perolehan N-gain tertinggi pada kelas eksperimen adalah pada sub materi mata yaitu sebesar $70 \%$ dan $\mathrm{N}$-gain terendah terjadi pada sub materi kamera yaitu sebesar 40\%. Sedangkan pada kelas kontrol, perolehan $\mathrm{N}$-gain tertinggi terjadi pada sub materi mata yaitu $71 \%$ dan perolehan $\mathrm{N}$-gain terendah terjadi pada sub materi kamera sebesar 39\%. Peningkatan N-gain yang lebih tinggi pada kedua kelas terjadi pada sub materi mata dan yang terendah terjadi pada sub materi kamera. Hal ini disebabkan karena instrumen tes pada sub materi kamera hanya sejumlah 2 soal yang terdiri dari aspek C1 (mengetahui) dan C6 (mencipta). Pada sub materi mata sebanyak 7 soal dalam ranah kognitif $\mathrm{C} 1$ hingga C5, dimana soal-soal tersebut sebagian besar termasuk dalam kategori mudah. Selain itu proses pembelajaran sub materi mata pada kelas eksperimen, peneliti 
menggunakan media virtual yang menyajikan beberapa animasi tentang mata dan cacat mata, dimana peserta didik mengerjakan tugas proyek yang disajikan dalam lembar kerja untuk melatih peserta didik dalam memperoleh konsepnya sendiri yang didapat dari media virtual tersebut. Sedangkan untuk sub materi kamera, pada kelas eksperimen pemberian materi hanya melalui tugas yang harus dikerjakannya. Hasil pengolahan data pada sub materi kamera menunjukkan peningkatan yang dicapai kedua kelas hanya berbeda $1 \%$, dengan peningkatan sebesar $40 \%$ untuk kelas eksperimen dan 39\% untuk kelas kontrol. Hasil ini menunjukkan bahwa informasi yang diterima mengenai konsep kamera pada kedua kelas cukup merata. Sejalan dengan penelitian Gunawan [19] yang menyatakan bahwa dengan pembelajaran virtual laboratory kemampuan membangun konsep lebih dapat ditingkatkan.

Berdasarkan penjelasan sebelumnya, selisih N-gain antara kelas eksperimen dan kelas kontrol terendah terjadi pada sub materi mata dan kamera. Jika dianalisis dari jumlah jawaban benar peserta didik per butir soal, didapatkan bahwa pada sub materi mata terdapat dua soal dimana semua peserta didik baik kelas eksperimen maupun kontrol menjawab benar, yaitu pada nomor soal 1 dan 2 , sedangkan pada sub materi kamera terdapat satu soal pada nomor 8 dimana semua peserta didik kelas eksperimen dan kontrol menjawab benar. Hal ini membuktikan bahwa kemampuan peserta didik pada sub materi mata cukup merata. Soal dengan jawaban benar peserta didik kelas eksperimen yang paling rendah ditemukan pada soal nomor 9, 20, dan 25 yang masing-masing memiliki persentase $32 \%, 32 \%$, dan $29 \%$. Jika dibandingkan dengan kelas kontrol, jumlah peserta didik yang menjawab benar pada soal tersebut juga sedikit yaitu berkisar $27 \%$, $42 \%$ dan $18 \%$. Hal ini disebabkan karena soal termasuk dalam tingkatan sukar, sedang dan termasuk dalam aspek kognitif yang tinggi, sehingga hanya sebagian peserta didik saja yang dapat menjawab soal dengan baik. Persentase jawaban benar peserta didik kelas kontrol pada nomor soal 20 lebih tinggi dibandingkan kelas eksperimen. Soal tersebut termasuk dalam tingkatan sukar dan kategori C3 (mengaplikasi), dimana peserta didik dituntut untuk memformulasikan persamaan matematis untuk menyelesaikan permasalahan dalam soal. Keunggulan tersebut dipengaruhi oleh kemampuan kelas kontrol yang memang cukup baik dan ketika pembelajaran sudah seringkali mendapatkan latihan soal dengan kategori tersebut sehingga akan memudahkan peserta didik dalam menjawab soal dengan baik.

Persentase jawaban benar peserta didik kelas eksperimen pada soal nomor 9 dan 25 lebih tinggi dibandingkan kelas kontrol. Keunggulan tersebut menandakan bahwa kelas eksperimen lebih mampu menjawab soal dengan baik karena konsep yang tertuang dalam soal lebih dikuasi, dengan melihat soal nomor 9 dan 25 termasuk dalam ranah kognitif tinggi yaitu C6 dan C4 dengan kategori sukar dan sedang yang tentunya membutuhkan kemampuan berpikir lebih tinggi untuk menyelesaikannya, dimana peserta didik harus menciptakan serta menganalisis cara penyelesaian masalah yang tertuang dalam soal. Beberapa penjelasan diatas mengungkapkan bahwa untuk meningkatkan penguasaan konsep fisika dapat diperoleh dengan meggunakan model project based learning. Penguasaan konsep akan lebih meningkat apabila penggunaan model tersebut dapat dioptimalkan dengan bantuan media virtual yang membimbing peserta didik untuk menemukan sendiri konsep yang sedang dipelajarinya.

\section{PENUTUP}

Berdasarkan hasil penelitian dan pembahasan, dapat disimpulkan bahwa terdapat pengaruh model project based learning berbantuan media virtual terhadap penguasaan konsep. Kelas eksperimen dan kelas kontrol mengalami peningkatan penguasaan konsep pada setiap sub materi dan aspek kognitif. Peningkatan pengusaan konsep pada kelas eksperimen lebih tinggi dibandingkan kelas kontrol. Hasil uji Ngain menyatakan bahwa peningkatan tertinggi pada kedua kelas terjadi pada sub materi mata sedangkan peningkatan terendah terjadi pada sub materi kamera.

Beberapa saran yang dapat diajukan peneliti untuk mengoptimalkan pemanfaatan model project based learning berbantuan media virtual yaitu: kemampuan awal hendaknya diperhatikan dengan baik agar pelaksanaan pembelajaran dapat mencapai hasil yang diharapkan; (2) dalam menerapkan model project based learning hendaknya mengatur sebaik mungkin alokasi waktu yang tersedia, sehingga tiap fase pembelajaran dapat berlangsung secara optimal, terutama alokasi waktu untuk pengerjaan proyek; (3) dalam penggunaan media virtual, hendaknya peserta didik bekerja mengoperasikan media secara mandiri agar peserta didik dapat bekerja lebih optimal.

\section{UCAPAN TERIMA KASIH}

Terima kasih disampaikan kepada Tim Hibah Penelitian Strategis Nasional Kemenristek Dikti Tahun 2016 yang telah melibatkan kami dalam penelitiannya, membimbing dan mengajarkan banyak hal, serta memfasilitasi semua proses hingga publikasi ilmiah bersama. Terima kasih juga disampaikan kepada Bapak Drs. Sahnan, M.Pd. selaku kepala SMAN 2 Mataram serta Bapak Akbar Riyadi, S.Pd selaku guru matapelajaran fisika dan seluruh kelas X.12 dan X.13 tahun ajaran 2015/2016 yang telah ikut serta dalam penelitian ini.

\section{REFERENSI}

[1] Prihatiningtyas, S., Prastowo, T., \& Jatmiko, B. (2013). Imlementasi Simulasi PhET dan Kit Sederhana untuk Mengajarkan Keterampilan Psikomotor Peserta didik pada Pokok Bahasan Alat Optik. Jurnal Pendidikan IPA Indonesia, 2(1). 
[2] Gunawan, G., Harjono, A., \& Imran, I. (2016). Pengaruh Multimedia Interaktif dan Gaya Belajar Terhadap Penguasaan Konsep Kalor Siswa. Jurnal Pendidikan Fisika Indonesia, 12(2), 118125.

[3] Badar, I. T. (2014). Mendesain Model Pembelajaran Inovatif, Progresif, dan Kontekstual. Jakarta: Prenadamedia Group.

[4] Yance, R. D. (2013). Pengaruh Penerapan Model Project Based Learning (PBL) terhadap Hasil Belajar Fisika Siswa Kelas XI IPA SMA Negeri 1 Batipuh Kabupaten Tanah Datar. Pillar of Physics Education, 1(1).

[5] Condliffe, B., Visher, M. G., Bangser, M. R., Drohojowska, S., \& Saco, L. (2016). Project Based Learning: Á literature review.

[6] Gunawan. 2015. Model Pembelajaran Sains Berbasis ICT. Mataram: FKIP Universitas Mataram.

[7] Bell, S. (2010). Project-based Learning for the 21st century: Skills for the future. The Clearing House, 83(2), 39-43.

[8] Thomas, J. W. (2000). A Review ff Research on Project-Based Learning.

[9] Askin, A. S. A. N., \& Haliloglu, Z. (2005). Implementing project based learning in computer classroom. TOJET: The Turkish Online Journal of Educational Technology, 4(3).

[10] Aldrich, C. (2009). Learning Online With Games, Simulations, And Virtual Worlds: Strategies For Online Instruction (Vol. 23). John Wiley \& Sons.

[11] Gorghiu, L. M., Gorghiu, G., Alexandrescu, T., \& Borcea, L. (2009). Exploring Chemistry Using Virtual Instrumentation-Challenges and Successes. Research, Reflections and Innovations in Integrating ICT in Education, 1, 371-375.

[12] Oidov, L., Tortogtokh, U., \& Purevdagva, E. (2012). Virtual Laboratory for Physics Teaching. In International Conference on Management and Education Innovatio, IPEDR (Vol. 37, pp. 319323).

[13] Dahar, R.W. (2011). Teori-teori Belajar dan Pembelajaran. Jakarta : Erlangga.

[14] Anderson, L. W., \& Krathwohl, D. R. (2015). Kerangka Landasan untuk Pembelajaran, Pengajaran, dan Asesmen: Revisi Taksonomi Pendidikan Bloom. Diterjemahkan oleh Agung Prihantoro. Yogyakarta: Pustaka pelajar.

[15] Silaban, B. (2014). Hubungan Antara Penguasaan Konsep Fisika dan Kreativitas dengan Kemampuan Memecahkan Masalah pada Materi Pokok Listrik Statis. Jurnal Penelitian Bidang Pendidikan, 20(1), 65-75.

[16] Zacharia, Z. C. (2007). Comparing And Combining Real And Virtual Experimentation An Effort To Enhance Students' Conceptual Understanding Of Electric Circuits. Journal of Computer Assisted Learning, 23(2), 120-132.

[17] Herga, N. R., Čagran, B., \& Dinevski, D. (2016). Virtual Laboratory in the Role of Dynamic Visualisation for Better Understanding of Chemistry in Primary School. Eurasia Journal of Mathematics, Science \& Technology Education, 12(3), 593-608.

[18] Rais, M., \& Ardhana, W. (2014). Project-Based Learning vs Pembelajaran dengan Metode Ekspositori dalam Menghasilkan Kemampuan Belajar Teori Perancangan Mesin. Jurnal
Pendidikan dan Pembelajaran (JPP), 20(1), 3344.

[19] Gunawan, G., Setiawan, A., \& Widyantoro, D. H. (2014). Model Virtual Laboratory Fisika Modern untuk Meningkatkan Keterampilan Generik Sains Calon Guru. Jurnal Pendidikan dan Pembelajaran (JPP), 20(1), 25-32.

\section{Biografi Penulis}

Ni Made Yeni Suranti, lahir di Mataram 12 Agustus 1994. Penulis menyelesaikan studinya di SDN 41 Mataram pada tahun 2006, SMPN 6 Mataram pada tahun 2009, dan SMAN 2 Mataram pada tahun 2012. Kemudian melanjutkan pendidikan S-1 di Universitas Mataram pada program studi pendidikan fisika hingga meraih gelar sarjana pendidikan pada tahun 2016. 